Владица Тодоровић

Универзитет у Београду

Факултет политичких наука

vladicatodorovic72@gmail.com

DOI: 10.18485/rit.2021.19.36.6
УДК: 271.222(497.11)-674(497.7)

271.222(497.11)-674(497.16)

$323.1(497.16)$ "19/20“

323.1(497.7)“19/20“

Ориганални научни рад

Datum prijema: 21.03.2021.

\title{
РАЗЛИКЕ И СЛИЧНОСТИ У ПОКУШАЈИМА ФОРМИРАНА АУТОКЕФАЛНИХ ЦРКАВА У СЕВЕРНОЈ МАКЕДОНИЈИ И ЦРНОЈ ГОРИ
}

\begin{abstract}
Резиме
У раяу смо се бавили йокушајима формирања ауйокефалних иркава у gве gржаве: Северној Макеgонији и Црној Гори.У ове gве яржаве живи йравославно сйановнишитво йоg јурисяикиијом Срйске иравославне иркве. Међуииим, у gве државе йостиоје захиеви за формирањем ауйокефалних иркава. У Рейублий Макеgонији, која је gанас држава Северна Макеgонија, као јеgној оg шесй рейублика Социјалисииичке феgерайивне рейублике Јуіословије је 1967. неканонски ироїлашена ауйокефалносии Макеgонске иравославне иркве, gок је у Црној Гори као gелу Савезне рейублике Јуіославије, коју је још чинила и Србија, 1993. формирана орі̄анизаиија йоg називом Црноіорска ирравославна ирква, и gеценијама йосйоји иокрей за ауйокефалносии иркве. Затио смо истиражили разлике и сличностии у йом ирроцесу у gве државе.
\end{abstract}

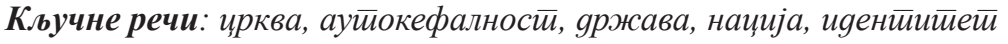

\section{Увод}

У раду смо се бавили захтевима за аутокефалним црквама у Северној Македонији и Црној Гори, државама у којима живи бројно становништво православне вере, које је под јурисдикцијом Српске православне цркве. У Северној Македонији, иако Македонска православна црква није у канонском јединству са Српском првославном црквом, православно становништво је номинално под јурисдикцијом Српске православне цркве, и у Црној Гори, православно становништво је под јурисдикцијом Српске православне цркве.

Дуго постоји спор о идентитету православних Македонаца. У Краљевини Срба, Хрвата и Словенаца (1918-1929) и Краљевини Југославији (1929-1941) Македонци као нација нису били признати, већ су били сврстани у Србе.Претпостављмо, делом и јер је у новијем периоду Македонија од 1913. до 1918. била део Србије, и као део Србије ушла у Краљевину СХС. 
Али Комунистичка партија, надолазећа политичка снага признавала је македонску али и црногорску нацију.

На петој земаљској конференцији Комунистичке партије Југославије у Загребу (октобар 1940) било је прихваћено да пет југословенских нација треба да чине Срби, Хрвати, Словенци, Македонци и Црногорци (Раковић, 2015: 56).

Тек након другог светског рата, са победом Комунистичке партије, и формирањем комунистичке Југославије, и Републике Македоније, као једне од шест република, Македонци добијају признање и политичке и етничке македонске нације. Македонци имају свој македонски језик, иако сличан српском, македонски је посебан језик. Али да би се национални идентитет Македонаца заокружио, била је потребна и Македонска православна црква. У Македонији не живи велики број Срба, који би се претпостављамо противили аутокефалности Македонске православне цркве. Огромна већина православаца су национални Македонци, који желе аутокефалну цркву.

Приликом оснивања Краљевине Срба, Хрвата и Словенаца 1918. није било признате ни црногорске етничке нације, већ су православци у Црној Гори сврстани у Србе. Црна Гора је призната на Берлинском конгресу 1878. Дакле, од тада постоји црногорска политичка нација, нација која има државу. Црна Гора се најпре 1918. ујединила са Србијом, па је потом формирана Краљевина СХС. Од тада до 1945. православни становници Црне Горе су убрајани у Србе. Али на попису становништва 1948. већина становника православне вере се изјашњавају као Црногорци. Приказали смо изјашњавање православних Црногораца на пописима становништва, пре другог светског рата, као и након другог светског рата, где видимо драстичне промене у националном изјашњавању православаца. Од 1990-их један број оних који се изјашњавају као национални Црногорци, траже независну Црну Гору и аутокефалност цркве у Црној Гори, да би заокружили државу и идентитет православних Црногораца. Они који се изјашњавају као Срби у Црној Гори, којих је велики број, противе се аутокефалности цркве у Црној Гори, јер би изгубили важан идентитетски ослонац, и били асимилавани у националне Црногорце.

\section{Формирање македонске нације}

Дуго су кроз историју претензије на територију данашње Северне Македоније показивале Бугарска, Србија, и Грчка. Свака од ових држава је имала своје разлоге за такве намере, а и дан данас се позивају на неке периоде у 
историји, у којима су владале овом територијом,односно када је ова територија била у саставу ових држава.

Године 1861. патријаршија (Цариградска) са руском претензијом поставила је четворицу Бугара епископа и доделила неку црквену аутономију. Тако се словенско ширење протеже постојано у Македонији и систематизује се стварањем Бугарске Егзархије 1870. године у Цариграду које је поделила национално православне хришћане Балкана са циљем бројчаног пораста Словена. Уз помоћ Турске, границе Бугарске Егзархије проширују се непрекидно ка југу. Од Ниша су пренете до Велеса 1874. обухватиле су митрополије Охрида и Скопља 1894. Струме и Неврокопа а 1897. Дебра и Битоља (Марку, 1994: 15-16). Почетком јула 1903. бугарски официри обилазе Македонију да подигну месно становништво са паролом: Македонија - Македонија, Стара Бугарска. Нису међутим успели јер Грчки народ Македоније није се подигао и никада није могао да замисли Македонију Бугарском (Марку, 1994: 17). Димитар Влахов вели: „Хисторијски, македонски ослободилачки покрет датира од дана када је основана Унутрашња македонска револуционарна организација. Ова организација, позната под именом ВМРО (Внутрешња македонска револуционарна организација) основана је 1883. године. Димитар Благојев, оснивач и вођа бугарских социјалиста, из чије је средине касније постала Бугарска комунистичка партија (БКП) сматрао је словенски живаљ на подручју географске Македоније Бугарима“ (Слијепчевић, 1996: 15). Припадници ВМРО су себе сматрали Македонцима, али не толико у националном смислу колико у смислу припадности ширем вишенационалном простору коме се ова организација заправо обраћала. У бугарски етнички карактер македонских Словена готово да се није сумњало (Јовановић, 2011: 50). Иако је српска пропагандна активност у Македонији била жива још у доба друге владавине кнеза Михајла (систем Гарашанинових повереника и агената), опсежан и конкретан државни план Србије за деловање на тим просторима направљен је тек 1885. Тај план се материјализовао кроз оснивање српских црквено - школских установа у Старој Србији и Македонији. Од 1890.године у српској пропагандној акцији поново узимају примат конзулати. Установљен је Просветни одбор као саветодавни орган, али он није остварио предвиђену улогу. У Стару Србију и Македонију се почињу слати „учитељи са квалификацијама“, занатлије, отварају се књижаре, у помоћ прискачу и трговци (Јовановић, 2002: 18). Немачки византолог Х. Гелцер писао је 1910. да „ни само становништво то не зна мислећи на национално опредељење Македонаца“ а Стојан Протић, каже да Наполеонови официри су после 1808. извештавајући 
са пута по Македонији, помињали искључиво Србе и српски језик (Јовановић, 2002: 23). Букурешким миром (10. август 1913), који у македонској историографији фигурира као „черечење Македоније“, Србија је добила северну и средњу, а Грчка јужну Македонију (Јовановић, 2002: 27). Генерал Милан Недић је у разговору са Иваном Мештровићем изјавио како би пре било какве заједнице са Бугарима требало потпуно посрбити Македонце, за шта је предвиђао 25 година: „Може бити да су Македонци јаки и вриједни, али држава ће бити јача од њих, па нешто милом, а нешто силом...Сила мијеси и твара нације, господине Мештровићу, па ће тако и наша држава од Македонаца направити и добре грађане и добре Србе“ (Јовановић, 2011: 256). Јасно је да се православни Македонци нису осећали Србима, и да је државни апарат хтео да утиче на њихово национално опредељивање.

Страни аутори увиђају парадоксални контраефекат који је имала неспретна југословенска политика на самоодређење Македонаца, нарочито након убиства краља Александра. Агресивна национална пропаганда је више отуђила и одбијала него што је послужила асимилацији. Иако македонско становништво још увек није било кадро да се прецизно идентификује, оно је јасно знало што није: „нису Срби!““ Слична ситуација била је и у време бугарске окупације 1941: „У међуратном периоду Македонцима је речено да су они Срби из Јужне Србије, сада су сазнали да су Бугари из Македоније. Третирајући Македонце као своје „заостале рођаке“ Бугари су их нехотице убедили да, поред тога што нису Срби, они нису били ни Бугари. Један од незграпних покушаја брзе бугаризације становништва било је отварање осамсто бугарских школа, довођење учитеља и егзархијских свештеника, што је изазвало револт и јачање партизанског покрета на крају (Јовановић, 2011: 47). Словенско становништво у Македонији није имало до краја изграђену националну свест, тако да су на националну опредељеност становништва покушавале да утичу државе које су претендовале на ову територију. А живео је у Македонији и одређен број Бугара, Срба и Грка, као домицилно становништво.

У Краљевини Срба, Хрвата и Словенаца, формираној 1918. није био признат национални македонски идентитет, већ су Македонци сврстани у Србе. Једно од обележја нације је и језик. Тако је Љуба Стојановић, из Југословенске републиканске странке, анализирао језик којим говори становништво на југу нове државе.

Љуба Стојановић, је као филолог, сматрао да је македонски дијалект посебан, ни српски ни бугарски (Батаковић, 2000: 281). Чешки професор Л. 
Нидерле признао је да са филолошког гледишта ,језик Словена македонских представља један скуп локалних дијалеката, доста различитих један од другога" и да је у том смислу неко средње наречје између српског штокавског и „правог“ бугарског језика (Јовановић, 2002: 22-23). Временом је признат македонски језик, али и посебна македонска нација.

Поред националних странака, све утицајнија политичка снага у Краљевини СХС била је Комунистичка партија, која је имала свој поглед на националне односе у новоформираној држави.

Комунистичка партија Југославије је на изборима од 28. новембра 1921. године имала 15 посланика у Македонији .Овакав успех КПЈ у Македонији дошао је тада не због њезине тадашње националне политике, него због њезиног већега залагања за права радника и сељака: „Иако још није имала одређено правилан став по македонском националном питању КПЈ се афирмирала у очима македонског народа као одлучан борац за права народних маса проти експлоатације и националнога угњетавања како каже Александар Апостолов“ (Слијепчевић, 1996: 23). У Резолуцији V Конгреса Коминтерне, држанога јуна 1924. године тражи се разбијање Југославије и отцепљење од ње народа који је сачињавају. У односу на паролу КПЈ о праву народа на самопредељење Резолуција Коминтерне истиче, да се ова парола „мора изразити у форми издвајања Хрватске, Словеније и Македоније из састава Југославије и стварања од њих независних република“ (Слијепчевић, 1996: 22). Пре Стаљиновог позива на устанак против Немаца, крајем јуна 1941, комунисти у Хрватској и Македонији прихватили су распад Југославије у априлу 1941. као испуњење националних захтева: исказали су спремност да раде у новим државним оквирима (НДХ и Велика Бугарска). Унутрашња македонска револуционарна организација (ВМРО) по инспирацији пробугарска, све је више, после 1918, добијала одлике класичне терористичке организације. Њени вођи, Тодор Александров, Александар Протогеров, а затим Ванчо Михаилов, са седиштем у Софији до 1934, убацивали су као у турско доба, комите у источну Македонију. ВМРО је упадао најчешће у источну Македонију, где је постојало пробугарско расположење, док се у њеном западном делу највећи део словенског становништва осећао Сpбима. Лоша управа и економска заосталост, заједно с несигурним политичким приликама, успоравали су, и углавном онемогућавали, жељену интеграцију словенског становништва Македоније у српску нацију (Батаковић, 2000: 293-294). И македонски комунисти и македонски националисти су желели распад монархистичке Југославије, јер је нису доживели као своју др- 
жаву, желећи други државни оквир, у коме би развијали и свој идентитет, јер у овој држави није био признат македонски идентитет.

Бугарска војска је окупирала Македонију, у периоду другог светског рата, сматрајући окупацију ослобођењем своје територије, и формирајући свој административни апарат.

Њихова окупација није била само војничка и административна, него и црквена. Сви бугарски фактори, чак и Бугарска комунистичка партија, сматрали су окупацију Јужне Србије ослобођењем њихове Македоније, која је све до исхода Балканских ратова, била под црквеном влашћу бугарске Егзархије и Васељенске патријаршије. Протерани су српски црквени великодостојници Јосиф Цвијовић и Викентије Проданов. Са бугарском окупацијом почело је интензивно бугаризирање православне цркве у Јужној Србији. Доведени су не само епископи, него и парохијски свештеници и монаси (Слијепчевић, 1996: 41). Године 1941, 4. маја митрополит Јосиф протеран је из Скопља, и кренуо је пут Београда возом (Митрополит скопски Јосиф, 2008: 135). Током II Светског рата Бугарска следећи армију Хитлера продрла је опет у Источну Македонију и Западну Тракију. После априла 1941. Бугари су се предали једном новом покушају етнографске промене грчких области које беху заузели. Постављају Бугаре као органе Управе и Полиције и приступају одузимању имовине Грка грађана. Затварају грчке школе и забрањују употребу грчкога језика (Марку, 1994: 19-20). Јачањем партизанског покрета, нарочито после капитулације Италије у лето 1943. године, множио се и број свештеника који су помагали партизански покрет... Македонски партизани су при Главном штабу за Македонију, 15.октобра 1943. године, створили Верско повереништво и за верског референта поставили свештеника Вељу Манчевскога. Стварање Верског повереништва, које је обухватало девет парохија са тридесет села, представља почетак стварања македонске црквене организације под покровитељством комуниста (Слијепчевић, 1996: 42-43). На првом заседању Аснома 2. августа 1944. године присуствовала су два свештеника. А за члана Аснома 27. октобра 1944. године кооптиран је свештеник Методије Гогов (Слијепчевић, 1996: 44). Свештеници у Македонији прилазе партизанском покрету, јер су се поистоветили се са циљевима партизана и националном политиком формирања македонске територијалне јединице, и признања македонске нације. Наком победе комуниста у другом светском рату на простору Македоније, убрзано је стварање након територијалне јединице са територијалним органима власти и уобличавање македонске нације, која треба да има и своју аутокефалну цркву. 
Први попис након другог светског рата, јасно говори да су национални Македонци већина у републици Македонији. Приказаћемо само бројчани однос Македонаца и Срба.

Табела 1. Попис становништва у Републици Македонији 1948.

\begin{tabular}{l|l|l} 
Становника 1.152,986 & Македонци 789.648 & Срби 29.721
\end{tabular}

Извор: http://publikacije.stat.gov.rs/G1948/Pdf/G19484001.pdf

Овакав тренд изјашњавања становника Македоније се задржао за цело време трајања СФРЈ.

И у независној Македонији, није било промена у националном изјашњавању становништва.

\section{Табела 2. Попис становништва у бившој југословенској републици Македонији 2002.}

\begin{tabular}{|l|c|c|}
\hline Становника 2.022,597 & Македонци 1.297,981 & Срби 35,939 \\
\hline
\end{tabular}

Извор:https://sh.wikipedia.org/wiki/Popis_stanovni\%C5\%A1tva_2002._u_ Republici_Makedoniji

Пописи становништва јасно говоре да се становници Македоније, па Северне Македоније у огромној већини изјашњавају као национални Македонци. Дакле, имају свој идентитет, који желе да употпуне и са аутокефалном црквом.

\section{Оснивање Македонске православне цркве}

Свештеници из Македоније у фебруару 1945. године одржали су свој „црквено-народни сабор“ који није тражио ништа мање него обнављање Охридске архиепископије и стварање Македонске православне цркве, био је изабран и иницијативни одбор као орган у коме је стављено у дужност, да се стара о извршењу одлука овог скупа (Слијепчевић, 1996: 45). Законите епископе СПЦ у Јужној Србији протерали су Бугари, а комунистичке власти Југославије забраниле су им да се врате на своја места (Слијепчевић, 1996: 49).

Поводом поступака свештеника из Републике Македоније, СПЦ је издала саопштење. 
„Свети архијерејски синод не може признати никакву самосталну и независну цркву у Македонији, која је проглашена без приволе и сагласности Мајке цркве и њене канонске јерархије у тим крајевима“ (Слијепчевић, 1996: 49). За иницијативни одбор се вели да је он незаконито приграбио црквену управу у тамошњим епархијама и тиме ремети постојећи црквени поредак и руши јединство цркве стварајући раскол у цркви и неред (Слијепчевић, 1996: 50). Тражиоци отцепљења најпре су тражили пуно отцепљење од СПЦ, затим су пристајали да за епископе добију домороце и да у црквеној администрацији могу употребљавати свој дијалект (Слијепчевић, 1996: 54). НР Македонија добила је најзад домороце за своје епископе, добила је своју црквену организацију у МПЦ, оставши и даље у духовном и канонском јединству са СПЦ преко наше смерности-патријарха (Слијепчевић, 1996: 68). Црквена јерархија у Македонији је желела Македонце у својој црквеној администрацији, и на тај начин пропагирајући независност своје цркве, не желећи да Срби учествују у црквеној јерархији. А све је представљало припрему за проглашење аутокефалности, јер би се Срби у македонској црквеној јерархији противили аутокефалности.

Само девет година после тога, након што им је Патријарх Герман рукоположио неколико епископа домородаца, показало се да је за „Македонце“ аутономија била само одскочна даска, па су опет самовољно на „црквено-народном сабору“ у Охриду 19. јуна 1967. прогласили аутокефалност МПЦ (Марку, 1994: 6). Македонска православна црква је је прихватила грегоријански календар (Слијепчевић, 1996: 87). Македонска православна црква је уместо јулијанског увела грегоријански календар. Желела је да се и на тај начин одвоји од СПЦ, која је као и већина православнох цркава користила јулијански календар.

Преко државних власти „иницијативни одбор“ врши притисак на патријарха Гаврила да прихвати њихове незаконите и неканонске захтеве. У том циљу 10. маја 1947. године посетили су патријарха Гаврила генерал-мајор Љубодраг Ђурић, Лазар Колишевски, председник владе НР Македоније и јереј Милан Смиљанић. Разговор је вођен о цркви у НР Македонији, а по жељи генерала Ђурића разговору није присуствовао Скопски митрополит Јосиф. Генерал Ђурић, а потом и Лазар Колишевски говорили су о невољама које су Македонци трпели од велико-српске, велико-бугарске, велико-грчке пропаганде (Пузовић, 1997: 24). Видимо учешће, односно мешање државе у разговорима о црквеним питањима. Али из разговора јасно је да се Македонци не осећају у националном погледу ни Србима, ни Бугарима, ни 
Грцима. Већ имају свој идентитет, коме је потребна и своја, аутокефална црква. Дакле, не желе ни другу црквену јурисдикцију.

Незадовољни одлуком Светог архијерејског сабора Српске православне Цркве, Македонска православна црква је сазвала свој црквено-народни сабор у Охриду од 16. до 19. јула 1967. године. На том мешовитом скупу остварили су своје претње - самовољно су прогласили МПЦ аутокефалном (Покровитељ овог неканонског чина Броз одликовао је митрополита Доситеја „орденом југословенске заставе са лентом“ (Пузовић, 1997: 82). Дакле, поклопили су се интереси црквене организације у Македонији и владајуће Комунистичке партије, која је формирала македонску територијалну јединицу и признавала постојање македонске нације, и пре освајања власти.

Новонастала ситуација извазвала је пажњу Васељенске патријаршије са седиштем у Истанбулу.

Васељенски патријарх Атинагора се писмом од 18. јула 1968. године обратио патријарху Герману интересујући се „докле се дошло са питањем такозване Македонске цркве“. Свети архијерски синод је на седници 8. септембра исте године упознат са садржином овог писма. Патријарх Герман је замолио патријарха Атинагору „да се молите за Српску православну цркву да је Господ спасе и избави од искушења а представнике тзв. „Македонске цркве, ако Вам се обрате поново, посаветујте да се уразуме и покају и врате у крило своје Мајке Цркве“ (Пузовић, 1997: 92-93). Априла 1969. Атинагора је писмом обавестио патријарха Германа да је добио информације да су представници такозване МПЦ путовали у Рим без позива и да нису били примљени у аудијенцију од стране папе Павла VI иако су то тражили (Пузовић, 1997: 97). Македонска православна црква је желела да интернационализује питање свог статуса, и због тога је тражила подршку Римокатоличке цркве, можда желећи да припрети уласком и у канонско јединство, односно унију са Римокатоличком црквом.

После три године чекања да се виша јерархија тзв. МПЦ покаје и врати у крило Мајке Цркве, епископ Жички Василије 20. априла 1970. године доставио је Светом архијерејском синоду оптужницу против виновника стварања верске расколничке организације. Свети архијерејски сабор на свом редовном заседању 20. маја 1970. године размотрио је оптужницу и вратио је Светом архијерејском синоду да је у потпуности саобрази прописима. После ове одлуке у документима нема трага да је оптужница поново покретана (Пузовић, 1997: 97). Лист „Осерваторе Романо“ бр. 117 од 23. маја 1970. године на стр. 1 донео је фотографију и вест да је папа примио у приватну аудијенцију 
једну делегацију Социјалистичке Републике Македоније, коју су предводили архиепископ Доситеј, Ванко Апостолоски, председник Скупштине Републике и Вјекослав Цврља, изасланик Југославије при Светој столици (Пузовић, 1997: 97-98). Кардинал Жан Виледебранс писмом бр. 2213 од 25. маја 1970. године обавестио је патријарха Германа о посети македонске делегације: „... Римска црква поштује Православну цркву и не може да се меша у једно питање њеног унутрашњег живота и у односе између разних аутокефалних цркава. Стога, ако аутокефалија неке Цркве није призната од стране аутокефалних православних држава, Римска црква не може ступити у званичне односе са том Црквом“ (Пузовић, 1997: 98). Видимо да су представници Македонске православне цркве и даље тражили подршку Римокатоличке цркве.

Кључни тренутак за формирање македонске етничке нације је формирање Републике Македоније 1945, када је формирана македонска политичка нација. Република у којој ће се дефинитивно формирати македонска етничка нација, са територијом, језиком, црквом.

Са распадом СФРЈ, наступила је нова ситуација, јер је Македонија, под називом Бивша југословенска република Македонија, због противљења грчких власти да држава користи име Македонија, 1992. постала независна држава. Зато је распадом Југославије питање цркве добило нову димензију.

Свети архијерејски синод СПЦ, се писмом од 23. марта 1992. године обратио влади Македоније са молбом да Српској православној Цркви омогући несметану духовну и пастирску делатност међу Србима у Македонији. То између осталог подразумева.

- Враћање Српској православној Цркви у посед одговарајућих храмова и манастира, са свим некретнинама и целокупним покретним благом: сакралним и другим културно-уметничким предметима, старим повељама, рукописима, књигама, архивским списима, итд.

- пастирско деловање међу православним Србима свештеника и вероучитеља Српске православне Цркве.

- успостављање одговарајућих територијалних јединица-парохија и епархија - Српске православне Цркве међу православним Србима у Македонији.

- рестаурацију и одговарајућу заштиту црквено-историјских споменика и задужбина владара, властеле и клирика на територији данашње Македоније, уз стављање под међународну заштиту УНЕСКО-а највреднијих културно-историјских споменика међу њима (Пузовић, 1997: 106). 
Након распада СФРЈ, македонске власти су спречавале улазак и пропутовање свештеника Српске православне цркве у Македонију и кроз Македонију (Пузовић, 1997: 108). Године 1994. Свети архијерејски сабор СПЦ на седници од 31/18. маја 1994. године позвао Македонску православну цркву да се у року од три месеца врати канонском поретку, или ће покренути против њих канонски кривични поступак (Пузовић, 1997: 109).

Али када се Македонска православна црква, није вратила у канонски поредак у заједничкој држави, илузорно је то очекивати у независној македонској држави.

Озбиљнији напредак догодио се 2002. када је потписан Нишки споразум 2002. који Македонцима даје широка овлашћења, а укључује и предлог за промену имена у Охридска архиепископија. Убрзо након потписаног споразума епископи МПЦ повлаче потпис. Тада патријарх српски шаље позив свим епископима понаособ да ступе у литургијско и канонско јединство са СПЦ, а преко ње и са осталим Православним Црквама. Једини који се одазвао и приступио јединству је Митрополит велеско-повардарски Јован, који је после тога избачен из митрополије, суђено му је за измишљене грехе, осуђиван је и затваран у неколико наврата на вишегодишње затворске казне (Лунић, 2020: 151).

Македонска православна црква, иако непризната функционише на територији, најпре републике Македоније, па независне државе настале 1992. и огромна већина националних Македонаца жели аутокефалну цркву. Формирана је 2002. Православна охридска архиепископија СПЦ, на челу са архиепископом Јованом Вранишковским, али није привукла велики број верника, што јасно показује да македонски народ жели аутокефалну цркву.

Канонска јерархија броји четири архијереја, мањи број нижих архијереја, док расколничка јерархија има десет епископа и већи број ниже јерархије (Лунић, 2020: 151).

Македонска православна црква се нада да ће Васељенска патријарши$\mathrm{ja}$, а по моделу Православне цркве Украјине, имати одлучујући глас по питању аутокефалности а не Српска православна црква. Јер у Македонској православној цркви виде да Српска православна црква од 1967. не мења став у овом питању.

\section{Нација у Црној Гори}

Црна Гора је 1878. на Берлинском конгресу постала независна држава. Тиме је створена црногорска политичка нација, нација која има своју држа- 
ву. Први попис становништва одржан је 1909. Од становника Црне Горе је тражено да се изјасне само о верској припадности а не о националној припадности. Али на попису становништва од 1921. је од становника Црне Горе тражено да се изјасне о националној припадности.

Приказаћемо само бројчани однос Црногораца и Срба, на овом као и на наредним пописима становништва.

\section{Табела 3. Попис становништва 2003.}

Становника 249338

Извор: Желидраг Никчевић, 2006, 164.

Милорад Екмечић наводи да је у меморандуму владе краљевине Црне Горе, Лиги народа у марту 1920. наведен нацрт етногенезе Црногораца, као посебне нације, настале асимилацијом досељеника и старих Илира. Разликује им се језик од српског и у средњем веку су имали моћну државу Зету (Екмечић, 2007: 370). Након првог помињања црногорске етничке нације 1920. следеће 1921. је одржан попис становништва у Црној Гори. Али као што видимо тај став није утицао на национално опредељивање становника православне вере, јер су се сви изјаснили као национални Срби. Дакле, нико се није изјаснио као национални Црногорац.

Пред формирање Краљевине СХC 1918. Црна Гора се најпре ујединила са Србијом па је створена Краљевина СХС. Али дошло је до поделе у Црној Гори, на бјелаше који су за безусловно уједињење са Србијом, што су показали на Подгоричкој скупштини и зеленаше који су се противили нестанку Црне Горе, и који су се залагали за федерално уједињење, у коме би Црна Гора имала федералан статус.Подела у почетку није била национална. Али је ипак представљала поделу, која се дуго одржала, чак и до данашњих дана.

Важно је истаћи да током двадесетих година ни Дрљевићеви федералисти, ни Штедимлија (као ни зеленаши раније), ни не помишљају да говоре о некаквој посебној црногорској нацији. Они себе дефинишу као Србе, а своје незадовољство излажу искључиво у оквиру политичких и статусних термина сматрајући да Црногорци (као део српског корпуса) и сама Црна Гора заслужују бољи статус од оног који имају као део Краљевине СХC, па чак и касније као бановина (Ђурковић, 2013: 129).

Црногорска нација након меморандума избегличке владе промовисана је и на трећем конгресу Комунистичке партије одржаном 1926. у Бечу. 
У резолуцији се каже „да је империјалистичка политика српске буржоазије изазвала силно незадовољство код свих несрпских нација у које си убројани и Црногорци“ (Вујовић, 2003: 136). Али сада већ учестало помињање црногорске етничке нације није проверено на попису становништва 1931. јер се од грађана није тражило изјашњавање о нацији, већ је тражено само изјашњавање о верској припадности. Али након другог светског рата када је Комунистичка партија освојила власт, тражено је национално изјашњавање становника Црне Горе.

\section{Табела 4. Попис становништва 1948.}

\begin{tabular}{|l|l|l|}
\hline Становника 377189 & Црногорци 342009 & Срби 6707 \\
\hline
\end{tabular}

Извор: Желидраг Никчевић, 2006,165.

На овом попису становништва се први пут појављују и они становници Црне Горе који се изјашњавају као национални Црногорци, док се мали број становника изјашњава да припада српској нацији. Тај тренд се задржао и на пописима 1953, 1961, 1971, 1981, 1991.

Дакле, видимо промену у идентитету православних Црногораца након освајања власти од стране Комунистичке партије, која је признавала постојање етничке црногорске нације и пре освајања власти. Тада долази до драстичног смањена броја Срба у Црној Гори, и до појављивања оних становника који се изјашњавају као Црногорци, а који постају огромна већина становништва у Црној Гори. Такав тренд изјашњавања становништва се одржао за цело време трајања комунизма.Са падом комунизма и демократизацијом, временом долази и до промене у изјашњавању становника Црне Гоpe. То видимо на попису становништва из 2003.

Табела 5. Попис становништва 2003.

\begin{tabular}{l|l|l} 
Становника 620 145 & Црногорци 267669 & Срби 198414
\end{tabular}

Извор: Желидраг Никчевић, 2006, 166.

Видимо да се на попису из 2003. драстично повећао број Срба, у односу на попис из 1991, што је значило и смањење броја Црногораца. Након три године од овог пописа Црна Гора је по други пут у својој историји постала независна 2006. након одржаног референдума на коме је 55,5\% станов- 
ништва гласало за такав статус, наспрам 44,5\% становништва које је гласало против.

\section{Табела 6. Године 2011. у сада независној Црној Гори, одржан је попис становништва}

\begin{tabular}{|l|l|l|}
\hline Становника 620029 & Црногорци 278 865 & Срби 178110 \\
\hline
\end{tabular}

Извор: MONSTAT-Zavod za statistiku Crne Gore, 2011

У околностима независне државе и од стране власти појачане идентитетске црногорске политике на попису становништва 2011. су били нешто другачији резултати Власт је желела да консолидује црногорску нацију и независну државу, и да постигне преко 50\% оних који се изјашњавају као Црногорци. Међутим, након пописа и даље национални Црногорци, нису прешли $50 \%$ становништва.

Примећујемо да када се са падом комунизма 1990. поправља положај СПЦ у Црној Гори, односно Митрополије црногорско-приморске, повећава и број Срба, што видимо на попису из 2003. Српска православна црква је важан идентитетски ослонац Срба у Црној Гори и зато је власт ДПС-а желела да укине СПЦ и прогласи аутокефалну цркву, јер би Срби ако би желели да одлазе у цркве СПЦ морали да одлазе у Србију или Републику Српску, што је тежи начин да се одржи идентитет, и временом би били асимиловани у етничке Црногорце.Али, већина православаца у Црној Гори не жели аутокефалну цркву.

Године 2006. Црна Гора је постала независна држава, и тек тада је настала права опасност за Српску православну цркву у Црној Гори, јер се од тада сваки став политичара из Србије о питањима важним за Србе у Црној Гори, третира као мешање у унутрашње ствари независне државе.

\section{Црквено питање у Црној Гори}

У даљем тексту ћемо приказати историјат јављања идеје о аутокефалној цркви у Црној Гори.

Аутокефална црква у Црној Гори проглашена је од стране књаза Николе Петровића. У Уставу Књажевине Црне Горе из 1905. стајало је „црногорска је црква аутокефална“. Када је Књажевина Црна Гора 1878. године призната као независна држава, књаз Никола Петровић је желео да изједначи 
статус цркве и владарске титуле са Србијом која је од 1879. имала аутокефалну цркву, а од 1882. краља (Раковић, 2015: 51). Због ових разлога је од стране књаза Николе, као световног владара, неканонски проглашена аутокефална црква у Црној Гори.

За време Другог светског рата од стране режима у Независној држави Хрватској 1942. долази до оснивања Хрватске православне цркве. Када је на чело ХПЦ постављен свештеник Руске заграничне цркве чије седиште је било у Сремским Карловцима, Гермоген, за његовог помоћника је постављен Савић Марковић-Штедимлија, који је за време другог светског рата заједно са Секулом Дрљевићем био вођа црногорских националиста.Штедимлија је по узору на оснивање ХПЦ дошао на идеју о оснивању Црногорске православне цркве (Алексић, 2002: 136). Након другог светског рата власт је желела да од јединствене СПЦ направи разједињену, а њену организацију прилагоди федералној организацији државе. План је био да се створе следеће аутокефалне цркве: црногорска, македонска, босанска, војвођанска, србијанска (Перић, 2006: 227).

У другом светском рату велики број свештеника Митрополије црногорско-приморске, на челу са Митрополитом Јоаникијем Липовцем, је страдао од окупатора и комуниста.

Након другог светског рата малобројни комунистима наклоњени свештеници одржали су 14. и 15. јуна 1945. године скупштину и донели Резолуцију. За ово време администратор црногорско-приморске митрополије био је митрополит Јосиф. У резолуцији свештенство се тражило:

- Да се православна цркве у Југославији, организује тако да буду равноправни сви православни без обзира на националну припадност.

- Не може примити митрополита Јосифа за администратора Митрополије ,због његовог тобожњег противнародног рада и због тога што сматра да им је наметнут, него тражи за администратора епископа тимочког Емилијана“.

- П Пошто не постоји ни архијерејски заменик ни Црквени суд „оснива своје привремено Свештеничко удружење које ће предложити архијерејскога заменика, да он у споразуму са администратором оживи црквени живот у Црној Гори и установи искрене односе са тамошњим државним властима“.

- Да ово Свештеничко удружење преузме иницијативу за сазив свештеничке скупштине православног свештенства Југославије ради оснивања Централног свештеничког удружења са задатком, да хит- 
но регулише положај Православне цркве у нашој земљи и односе између Федеративне Југославије и наше Православне цркве пошто то није учинио досадашњи Синод СПЦ и да тако држање Светог Синода не одговара интересима народа и Свете цркве, преко које се не могу спроводити никакве великосрпске шовинистичке идеје.

- Да се изведе демократско црквено уређење тако да се измени Закон и Устав СПЦ како би се дало право народу и свештенству да директно учествује у избору свих црквених представника (Слијепчевић, 2002: 166-167).

- Свети архијерејски Синод је саопштио да су Резолуцијом прекорачене дозвољене границе и да су самовласно узели на себе улогу да оно регулише положај Православне цркве у нашој земљи и епархије у Црној Гори мимо главе Цркве, његове Светости Патријарха и Светог архијерејског сабора, који је једино надлежан за то (Слијепчевић, 2002: 167). Али повратком из заробљеништва патријарха Гаврила Дожића, који је и сам из Црне Горе, престале су активности овог удружења.

Године 1987. идеју о аутокефалној цркви покреће Јеврем Брковић у београдском листу Дуга. У полемици са историчаром др Растиславом Петровићем покренуо је Штедимлијину тезу о тзв. „Црногорској православној цркви“. Годину дана касније, исту причу наметнуо је и адвокат Бранко Ђ. Никач (Алексић, 2002: 191).

Почетком 90-их година 20-ог века, са успостављањем вишестраначког система у Црној Гори, појављује се странке и личности које покрећу идеју о аутокефалној цркви. Реч је Либералном савезу и Црногорском федералистичком покрету, који је настављао традицију странке федералиста из времена пре другог светског рата, чији припадник је био и Секула Дрљевић.

У гласилу Либералног савеза - Либералу и Монитору савремени настављачи Штедимлијине и Дрљевићеве политике. Данило Радојевић, Радослав Ротковић, Бранко Никач, Војислав Никчевић, Рајко Церовић, Јеврем Брковић су објављивали текстове о тзв. Црногорској православној цркви. Они су 1990. основали и одбор за вртање аутокефалности црногорске цркве (Ђурковић, 2013: 144). Али видимо да је овај одбор био састављен од световних лица, која нису организована под окриљем Цркве.

Већина свештенства Митрополије црногорско-приморске на челу са Митрополитом Амфилохијем Радовићем се од самог почетка деловања покрета за аутокефалност противи том захтеву. Зато су световна лица, окупље- 
на у Одбору за повратак аутокефалности Црногорске православне цркве, морала за свој пројекат пронаћи свештеника који би се придружио покрету за аутокефалност.

У организацији овог одбора је 31. октобра 1993. на Цетињу за челника Црногорске православне цркве постављен Антоније Абрамовић, рођен у Котору, који је био припадник Православне цркве у Америци. Али је А. Абрамовић искључен од стране Светог Архијерејског Синода Православне цркве у Америци 23. марта 1995. (Раковић, 2015: 76). Када је А. Абрамовић преминуо за новог поглавара ЦПЦ 1996. постављен је Мираш Дедеић, свештеник митрополије Италије васељенске патријаршије, са службом у Риму. Али је он рашчињен 4. априла 1997. од стране Светог Синода Васељенске Патријаршије (Раковић, 2015: 78). Ова црква је регистрована 17. јануара 2000. Дуго није била регистрована, али када је власт отворено кренула шутем независне државе, ЦПЦ је регистрована. Али наредних деценија није привукла велики број грађана.

\section{Подршка власти аутокефалној цркви}

Покрет за независну Црну Гору од 1990. до 1997. није био јак у Црној Гори, нарочито није био јак међу становницима православне вере. Било је странака које су пропагирале независност и национални црногорски идентитет, на пример Либерални савез Црне Горе и Социјалдемократска партија Црне Горе, најјаче странке међу њима. Године 1997. долази до раскола у владајућој Демократској партији социјалиста Црне Горе, када због различитог мишљења око даље подршке политици Слободана Милошевића у Србији, у сукоб долазе председник Црне Горе Момир Булатовић и премијер Мило Ђукановић. Онај део странке који задржава име ДПС, који предводи М. Ђукановић, а који је победио у сукобу, почиње да се дистанцира од режима у Србији, наговештавајући да ће демократизовати Црну Гору.

Српска православна црква је подржала Мила Ђукановића, сматрајући да ће се демократизацијом побољшати и положај цркве. Тако је дошло да састанка у патријаршији у Београду и до сусрета Патријарха Павла, митрополита Амфилохија са једне стране, а са друге стране су састанку присуствовали Мило Ђукановић и Светозар Маровић.

Међутим, ова странка се све више да се дистанцирала од Србије. Политичари из ове странке почињу да говоре о равноправности Србије и Црне Гоpe, значајној дипломатској историји Црне Горе, туристичким потенцијалима, 
и све више о независној држави. Убрзо у СПЦ, ДПС види препреку у остваривању својих циљева и почиње да у медијима под својом контролом даје простор Црногорској православној цркви, која се залаже за независну Црну Гору. Демократска партија социјалиста постепено преузима програм Либералног савеза и почиње да се залаже за независну Црну Гору, са националним црногорским идентитетом одвојеним од српског, као и за аутокефалну цркву.

Мило Ђукановић је 10. јануара 2000. писао српском патријарху Павлу: „Молим Вас да својим ауторитетом утичете да се свештенство СПЦ у Црној Гори уздржи од исхитрених поступака који нису увијек у складу са основним хришћанским вриједностима“. Већ 17. јануара 2000. у полицијској станици на Цетињу пријављено је оснивање вјерске заједнице ЦПЦ“. Само две године од када је М. Ђукановић добио подршку СПЦ, за останак на власти, почиње да критикује СПЦ, јер је кренуо путем независне државе.

Мило Ђукановић је Васкрс 2000. (30 април) честитао и верницима СПЦ и присталицама ЦПЦ, Ђукановић је рекао да би било најбоље решење ако би се остварила тежња грађана Црне Горе који траже да се добије већа аутономија православне цркве (Раковић, 2019: 177). У том периоду власт је желела независнији положај Митрополије црногорско-приморске, јер се власт све више дистанцирала од Србије.

У јануару 2004. црногорски премијер М. Ђукановић честитао је Божић, свим вјерницима, свјештенству ЦПЦ, СПЦ и свим грађанима православне вјероисповјести у Црној Гори (Раковић, 2015: 94). Сада премијер Црне Горе, у честитки прво помиње ЦПЦ па СПЦ, јасно показујући коме даје примат.

У програм ДПС-а 2011. ушао је као циљ стварање аутокефалне цркве. Године 2011. на шестом конгресу, ДПС је усвојио нови страначки програм у којем је стајало и ово: „Пошто су православни вјерници у Црној Гори подијељени, превазилажењу ове подијељености најбоље погодује јединствена и организациона самосталност православне вјерске заједнице, уз пуно поштовање и афирмацију црногорског државног, националног и културног идентитета и међунационалног склада (Раковић, 2015: 105). Ђукановић је 16. маја 2011. на телевизији Црне Горе рекао: „Митрополија црногорско-приморска није усаглашена са државним интересима Црне Горе, јер је део СПЦ чија је централа у држави Србији која не гледа благонаклоно на црногорску независност. Стога ако желимо православну цркву у хармоничним односима с државом и црногорским државним органима, логични је циљ самосталност цркве (Раковић, 2015: 105). Црква и држава у Црној Гори нису у хармонији од 1945. са побољшањем односа од 1990. до 1997. са 
падом комунизма и демократизацијом, па су поново у сукобу од 1997. када власт ДПС-а мења политику о заједничкој држави. Није деловање СПЦ допринело да односи државе и цркве нису били у хармонији, јер црква није мењала „политику“ према заједничкој држави. Црква не може зависити од политичких странака које се у демократским државама, смењују на власти.А власт ДПС-а је од 1990. до 1997. мењала своју политику у погледу заједничке државе са Србијом. Важан податак је и да је већина православаца 2006. гласала за заједничку државу са Србијом, и да већина православаца не жели аутокефалну цркву.

У часопису Монитор, који је водио политику независне Црне Горе пише: „Питање нације, тако и ово питање цркве, неодвојиво је од питања црногорске државе. Негирањем једног или другог, негира се у ствари Црна Гоpa, и даље, црногорска црква и српска црква у њој; ту не може бити јединства, већ само сукоба...тај сукоб може бити разријешен тако што ће ово бити Црна Гора, народ црногорски и црква црногорска, или их у противном неће бити. Ако остане српска црква, Срби из Црне Горе и српска Спарта, онда је ту јасан епилог“ (Јевтић, 2009: 144-145). Они који се изјашњавају као Црогорци, и који су углавном чинили власт, сматрају да Црна Гора не може опстати без аутокефалне цркве, и чине све у наредном периоду да аутокефалност спроведу у дело.

Пошто СПЦ „није регистрована“ у Црној Гори према закону о правном положају вјерских заједница 1977. МУП Црне Горе је у децембру 2011. одбио да продужи боравишне дозволе неколицини пљеваљских свештеника СПЦ и погоричком пароху Велибору Џомићу. Наиме они нису били држављани Црне Горе и тражен им је доказ о регистрацији СПЦ у Црној Гори како би могли да наставе боравак у местима где су били на служби. Велибор Џомићу, је најпре ускраћен боравак, па враћена та могућност (Раковић, 2015: 107). И другим свештеницима и монасима, који нису из Црне Горе се претило ускраћивањем боравка, јер је власт желела да свештена лица и монаси буду само из Црне Горе, тзв. „домороци“ рачунајући да би се код њих јавила црногорска национална и државна свест и да би они у једном тренутку прогласили аутокефалност.

Министарство за људска и мањинска права Црне Горе упутило је 3. августа 2015. позив на јавну расправу о нацрту закона о слободи вјероисповести. У члану 11 територијална конфигурација вјерске заједнице која је регистрована и дјелује у Црној Гори не може се простирати ван Црне Горе, сједиште вјерске заједнице која је регистрована и дјелује у Црној Гори мора бити 
у Црној Гори. У члану 16 стоји да се назив вјерске заједнице мора разликовати од назива других вјерских заједница и не смије садржати службени назив друге државе и њена обиљежја. У члану 52 стоји, вјерски објекти и земљиште које користе вјерске заједнице на територији Црне Горе, а за које се утврди да су изграђени, односно прибављени из јавних прихода државе или су били у државној својини до 1. децембра 1918. као културна баштина Црне Горе, државна су својина (Раковић, 2015: 192-195). Чланови 11 и 16 сугеришу да центар верске заједнице мора да буде у Подгорици или Цетињу, а не као до сада у Београду, који је сада главни град друге државе. Док члан 52 говори о одузимању имовине СПЦ. Крајем 2019. 26. децембра усвојен је закон у скупштини Црне Горе, након кога су почели масовни протести становништва, пре свега православаца али и појединих припадника других конфесија. Као и неких припадника ДПС-а, који су били верници СПЦ. Протести су одржавани четвртком и недељом, и били су све масовнији, све до појаве вируса.

Суочен са највећим изазовом од независности Црне Горе 2006. М. Ђукановић је почео да посећује општинске одборе ДПС-а. На састанку општинског одбора у Тивту је рекао: „Не дозволите да се ваша вјерска слобода злоупотребљава ових дана по Црној Гори. А, злоупотребљава се да би се срушила Црна Гора. Не дозволите да будете дио тог лудачког покрета“ (РТРС, 2020). Лудачки покрет по лидеру ДПС-а је и даље неговати српски идентитет, када је Црна Гора независна, и жели црногорски идентитет са аутокефалном црквом.

Власт сматра да Црна Гора неће изаћи из културног и политичког круга док не добије аутокефалну цркву. Преко СПЦ су Црна Гора и Србија и даље повезане, а то је сметало режиму ДПС-а. На парламентарним изборима 30. августа 2020. долази до промене власти, у којој је СПЦ имала одлучујућу улогу, јер је анимирала вернике да изађу на изборе у великом броју.

У наредном делу текста ћемо представити услове које црква треба да испуни да би постала аутокефална, и упоредити са актуелном ситуацијом у Северној Македонији и Црној Гори.

\section{Фактори аутокефалије}

- Да су оснивачи цркве апостоли.

- Пуноћу црквене власти Христос је дао свим апостолима подједнако. Васељенски сабор је највиша власт у Цркви. Он има право да даје аутокефалију или да установљава ранг аутокефалних цркава. 
- Одлуку о аутокефалности доноси Сабор архијереја аутокефалне цркве. Тако је поступљено 1920. Пошто су претходно прибављени канонски отпусти за одређене епархије и сагласност Цариградске епархије (Перић, 2006: 163). Автокефали називали су се сви они епископи, који су имали под својом јурисдикцијом неколике епархије, и који су јурисдикцију, самостално вршили, независно од неког другог црквеног старјешине (Милаш, 2004: 258).

\section{Споредни фактори аутокефалије}

- Воља државне власти. Било је примера да се држава ненадлежно умешала у рад Цркве, тако је јерменски краљ Пап донео одлуку о аутокефалности цркве у Јерменији 374. године, бугарски цареви Петар и Асен су 1185. године дали аутокефалност Бугарима (Перић, 2006:164). У Уставу књажевине Црне Горе 1905. наведено је да је Црква у њој аутокефална, да не зависи ни од које друге Цркве, али да одржава догматске односе са Васељенском црквом. Да је заиста била аутокефална она би од Васељенске цркве тражила аутокефалност, а не би је развијала од свјетовне власти (Стаматовић, 1999: 71). Могли смо препознати поступке доскорашње црногорске власти, власти до 2020. да се умеша у црквено питању Црној Гори. Власт, која формирана почетком 2021. не жели аутокефалну цркву, односно већина која чини власт. У СФРЈ и Македонији 1967. државна власт се директно умешала у црквено питање.

- Воља цариградске цркве (Перић, 2006: 164).

- Воља осталих цркава осим Мајке цркве. Ни све остале аутокефалне цркве ако би се „сложиле“ да нека Црква буде аутокефална, не могу произвести правно дејство без Мајке Цркве (Перић, 2006: 164). Пример Црногорске православне цркве, и Мираша Дедејића у чијој хиротонији су учествовали бугарски расколници.

\section{Услови аутокефалије који се тичу средине која тежи аутокефалији}

- Верници. У делима апостолским говори се о томе да су апостоли и те како пазили на вољу светих-верника (Перић, 2006: 165). Већина верног народа у Црној Гори не жели аутокефалну цркву, иако се већина изјашњавају Црногорци (Јевтић, 2002: 143-144). Огроман број 
верника припада Македонској православној цркви, а не другим црквама (Саџаков, 30. мај 2019, Радио Слободна Европа).

- $\quad$ Свештенство. Поред воље народа, од значаја је и став свештенства тог народа. Ако би се догодило да народ без сагласности свештенства, или пак обратно, свештенство без народа затражи аутокефалију, то би био знак незрелог стања у тој средини које обично служи као отежавајућа околност да се аутокефалија добије.У нормалним приликама верници и свештенство се заједнички обраћају молбом за аутокефалију, што је знак сагласја тог дела Цркве (Перић, 2006: 165). Све свештенство на подручју Црне Горе заједно са поглаваром - Митрополитом је против акције за додељивање аутокефалије. Тако да њу захтевају лаици (Јевтић, 2002: 142-143). Прошла власт је желела да свештенство буде само из Црне Горе, рачунајући да ће код њих се јавити црногорска државна и национална свест. Иста ситиација је била у Македонији непосредно после другог светског рата, када су у Македонији они свештеници који су желели аутокефалну цркву тражили „домороце“ за свештенике у Македонији. Данас већина свештеника жели аутокефалну цркву, што видимо на примеру Православне охридске архиепископије, коју подржава мали број свештеника.

- Држава. Право на покретање питања за добијање аутокефалије може се признати само владару православне вере. Он, у споразуму, са свештенством и народом, покреће ово питање и даје му одговарајућу тежину.Ако је владар неправославан, не може му се дати право да тражи аутокефалну цркву (Перић, 2006: 166). Држава Црна Гора је постала независна 2006, али је већина православаца гласала за заједничку државу, 54,5\% православаца је гласало за заједничку државу, док је око 45,5\% православаца гласало за независност (Раковић, 2015: 98). Сада мањина православаца тражи аутокефалну цркву, а од краја 1990-их до 2020. сви председници и премијери су желели аутокефалну цркву. Променом власти 2020. и формирањем нове Владе, премијер се не залаже за аутокефалну цркву.Док у Северној Македонији већина православаца жели аутокефалну цркву, али и сви председници и премијери су желели аутокефалну цркву. Говоримо о деценијама, које сежу од другог светског рата, до данас. Тако, премијер Зоран Заев је у мају прошле године писао Патријарху Вартоломеју, подржавајући захтев Синода да се то најзад реши (Радио Слободна Европа, 30. мај 2019). 


\section{Закључак}

Македонска и црногорска нација су нације, које су конституисане или покушавају да се конституишу у новије време. Македонска нација је призната тек победом Комунистичке партије након другог светског рата. Црногорска нација је такође призната након другог другог светског рата, када је Комунистичка партија освојила власт, и почела да спроводи своју идентитетску политику.

Уследиле су деценије комунизма у којима су се учврстили и македонски и црногорски национални идентитет. Са падом комунизма 1990.-тих и демократизацијом, македонски национални идентитет је остао стабилан, између осталог и зато што је Македонија, под званичним називом „Бивша југословенска република Македонија“, стекла независност 1992. Са независношћу поставило се питање идентитета и симбола националних Македонаца, сада у независној, међународно признатој држави.

Након економске блокаде коју је увела Грчка средином 1990-их, власти у Скопљу су морале уклонити антички македонски симбол са заставе - тзв. сунце Вергине, грб династије Филипа Македонског, и заменити га осмокраким „новим сунцем слободе“ које се помиње и у македонској националној химни (Јовановић, 2014: 215). Спорно је било и име државе, Македонија.

Због грчких ставова о имену, Македонија се окренула против Грчке, и почела да радикално редефинише властити национални идентитет, како каже Дејан Јовић.

„Резултат тога је фасцинантан пројект конструирања новог Скопја Скопје 2014. Тим пројектом је готово у потпуности преобликован центар македонског главног града, и то са с политичком сврхом и поруком: да постоји изравна веза између сувремене Македоније и античких Македонаца. Сврха тог конструирања јест у стварању мита о дуготрајности македонског идентитета и о његову континуитету са старим, античким Македонцима“ (Јовић, 2017: 65). У Македонији су се идентитетска питања сад толико распламсала, да се нација подијелила на оне који вјерују да су Македонци Славени, и оне друге, који тврде да нису Славени него потомци античких Македонаца (Јовић, 2017: 65). Али сви православни Македонци су национални Македонци, без обзира шта мислили о свом пореклу. У Црној Гори је другачија ситуација.

За разлику од македонског идентитета, црногорски национални идентитет је све више почео да се дели на црногорски и српски. Црна Гора 1992. није постала независна, већ је 1992. постала са Србијом део Савезне репу- 
блике Југославије. И у том статусу је била до 2006. са прелазним периодом од 2003. до 2006. када је формирана државна заједница Србија и Црна Гора, орочена до референдума о статусу, када након референдума 2006. Црна Гора постаје независна држава. Кроз цео период од 1992. до 2006. је постојала идентитетска подела у православном становништву Црне Горе, а и након независности 2006. остала је подела на оне који сматрају да су национални Црногорци и на оне који сматрају да су национални Срби. Дакле, у православном становништву постоје различита мишљења о идентитету, историји, језику, статусу Црне Горе, аутокефалној цркви.

У једној и другој држави, Северној Македонији и Црној Гори, падом комунизма али и са стицањем независности две државе постоји спорно питање Српске православне цркве, с тим да је о том питању много већа подела у Црној Гори.

Однос цркве и државе у Северној Македонији је од 1945. до 1990. био добар. Комунистичка власт је подржала стварање аутокефалне цркве, јер је настојала да консолидује нацију у формирању, нацију која се територијално консолидовала, јер је добила Републику Македонију, а територија односно држава формира нацију, у македонском случају и учвршћује нацију у идентитету. И власт независне Македоније је имала добар однос са црквом, подржавајући је у настојању да добије аутокефалност. Док у Црној Гори од 1945. до 1990., није био добар однос цркве и државе, са извесним побољшањем од 1990. до 1997. када је пао комунизам, да би од тада постајао постепено све лошији однос са Српском православном црквом, јер је режим кренуо путем незвисне државе и аутокефалне цркве, што је погоршало односе СПЦ и власти у Црној Гори. Године 2011. у програм ДПС-а ушао је као циљ аутокефална црква. Године 2019. усвојен је закон о слободи вероисповести, чиме је тај лош однос кулминирао, јер је тадашња власт желела да отме и имовину СПЦ. Након усвајања закона, кренуле су масовне литије које су у великој мери утицале на парламентарне изборе 2020. након којих је поражен режим ДПС-а. Очекивано је да ће нова власт имати бољи однос према Српској православној цркви, односно Митрополији црногорско-приморској, јер власт подржавају и српске странке, а и у Влади Црне Горе има доста министара који се изјашњавају као Срби.

Македонија је независна, и већина становника православне вере жели аутокефалну цркву. Српска православна црква у Македонији је од 2002. у канонском јединству са Православнм охридском архиепископијом. Али охридска архиепископија није привукла велики број свештеника и верника. 
Године 1993.у Црној Гори основана је неканонска Црногорска православна црква, али ЦПЦ наредних деценија није привукла велики број свештеника и верника у Црној Гори. У томе је разлика у две државе, у броју свештеника и верника Српске православне цркве. Односно Охридске архиепископије која је у канонском јединству са СПЦ и бројчано веће у погледу свештеника и верника Македонске православне цркве, док је Српска православна црква у Црној Гори, бројчано већа у погледу свештеника и верника од Црногорске православне цркве.

Власт Комунистичке партије је након другог светског рата подржавала конституисање македонске и црногорске нације, али и аутокефалност цркве у тада две републике.

У Македонији је свештенство након другог светског рата подржало стварање аутокефалне цркве, и није променило мишљење до дан данас. Говоримо о огромној већини. Док у Црној Гори је било подршке за аутокефалну цркву у првим годинама након другог светског рата, али је брзо спласла та идеја.

После другог светског рата и у Црној Гори је комунистичка власт желела да спроведе аутокефалност цркве, али још увек православно становништво је имало свест о припадности српској нацији и Српској православној цркви, и није прихватило ту идеју. Док у Македонији православно становништво, очигледно се није осећало Србима, и зато је прихватило идеју о аутокефалној цркви.

Са падом комунизма и независношћу 1990-их власт у Македонији је желела аутокефалност цркве, а исто су желеле и странке опозиције националних Македонаца. Док власт у Црној Гори од 1990. до 1997. није желела аутокефалност цркве, већ су то желеле поједине опозиционе странке националних Црногораца.

Али када власт ДПС-а мења политику у правцу независне државе, почиње да пропагира и аутокефалну цркву. Личности наклоњене црногорском националном идентитету, власт ДПС-а и опозиционе странке наклоњене црногорском идентитету и независној држави Црној Гори, су подржавале ту идеју. Странке које су неговале српски идентитет и које су се залагале за заједничку државу са Србијом, али и већина православног становништва, нису прихватили ту идеју.

Македонска православна црква је прихваћена у Македонији, и нема у толикој мери поделе у питању македонске нације, македонски језик је прихваћен у становништву, статус Македоније међу већином православаца је неспоран. У Црној Гори постоје црногорска и српска нација, српски и црно- 
горски језик, статус државе је споран након референдума 2006. а био је споран и пре 2006. Али СПЦ је већински прихваћена у Црној Гори.

По условима за аутокефалију, које смо навели, Македонска православна црква испуњава услове за аутокефалну цркву, док не постоје услови за аутокефалност цркве у Црној Гори. Али не постоји договор Македонске православне цркве, са мајком црквом, Српском православном црквом. Свака црква тешко прихвата раскол, подсетимо се Римокатоличке цркве и Протестантске цркве, Римокатоличке цркве и Православне цркве, и у исламу постоји подела на шите и суните, бектеше, вехабије и разне друге поделе у исламу. Тако да је сличан случај и са Македонском православном црквом и Српском православном црквом, проблем за који није изгледно да ће се peшити у догледно време.

\section{Литература}

Алексић, Будимир (2002). Црвено-Црна Гора, Омладински интелектуални центар, Никшић.

Батаковић, Душан (2000). Нова историја српског народа, Наш дом, Београд.

Вујовић, Мишо (2003). Црња и Гора, Културни центар Свети Сава, Подгорица.

Ђурковић, Миша (2013). Тамни коридори моћи, Укронија, Београд.

Екмечић, Мирољуб (2007). Дуго кретање између клања и орања, Завод за уџбенике, Београд.

Јевтић, Мирољуб (2002). Религија и политика, Факултет политичких наукаИнститут за политичке студије, Београд.

Јовановић, Владан (2002). Југословенска држава и Јужна Србија 1918-1929, Институт за новију историју Србије, Београд.

Јовановић, Владан (2011). Вардарска бановина 1929-1941, Институт за новију историју Србије, Београд.

Јовановић, Владан (2014). Слика једне неуспеле интеграције, Фабрика књига, Београд.

Јовић, Дејан (2017). Рат и мит-политика идентитета у сувременој Хрватској, Фрактура, Загреб.

Лунић, Томислав (2020). „Македонски раскол-однос Православне охридске архиепископије и МПЦ“, Теолошки погледи, бр.1/2020, 145-160, Београд.

Марку, Илија (1994). Македонска црква-самотворевина Скопља улога Папе и Уније, ГП Нови дани, Београд.

Митрополит скопски Стефан (2008). Мемоари, Светигора, Цетиње.

Никодим, Милаш (2004). Православно црквено право, Епархија далматинска, Шибеник - Београд.

Никчевић, Желидраг (2007). Права Срба у Црној Гори, ИГАМ, Београд.

Пузовић, Предраг (1997). Раскол у Српској православној цркви-македонско црквено питање, Свети архијерејски синод Српске православне цркве, Београд. 
Перић, Димшо (2006). Црквено право, Правни факултет Универзитета у Београду Центар за публикације, Београд.

Раковић, Александар (2015). Религијски интервенционизам 1991-2015, Хришћански културни центар др Радован Биговић, Београд.

Раковић Александар (2019). Црногорски сепаратизам, Катена мунди, Београд.

Слијепчевић Ђоко (1996). Македонско црквено питање, ИП Архив доо, Нови Сад

Стаматовић, Александар (1999). Кратка историја Митрополије црногорскеприморске, Светигора, Цетиње.

Слијепчевић, Ђоко (2002). Историја српске православне цркве 3. том, ЈРМ, Београд.

Иниернети извори:

MONSTAT, https://www.monstat.org/userfiles/file/popis2011/saopstenje/saopstenje(1). pdf, Приступљено 16. март 2021.

РТРС, 2020, „Ђукановић литије назвао лудачким покретом“, Радио телевизија републике Српске, 21. јануар 2020. Приступљено 16. март 2020. https://rtrs.tv/ vijesti/vijest.php?id=367688.html

Radio Slobodna Evropa „Da li je SPC spremna na dijalog sa makedonskom crkvom o autokefalnosti“"? Pristupljeno 16. mart 2021. https://www.slobodnaevropa.org/a/ spc-mpc-dijalog/29971611.html

\title{
Vladica Todorović
}

University of Belgrade

Faculty of Political Sciences

vladicatorovic72@gmail.com

\section{DIFFERENCES AND SIMILARITIES IN EFFORTS TO FORM AUTOCEPHALOUS CHURCHES IN NORTHERN MACEDONIA AND MONTENEGRO}

\begin{abstract}
Summary
In this paper, we analyze the efforts to form autocephalous churches in two countries: Northern Macedonia and Montenegro. The Orthodox population that lives in these two countries belongs to the Serbian Orthodox Church. Regardless, there are ongoing demands in these countries for the formation of autocephalous churches. In the Republic of Macedonia, now called the state of Northern Macedonia, as one of the six republics of the Socialist Federal Republic of Yugoslavia, the autocephaly of the Macedonian Orthodox Church was uncanonically declared in 1967. In Montenegro, which along with Serbia constituted the Federal Republic of Yugoslavia, in 1993 an organization called the Montenegrin Orthodox Church was formed. A movement for the church's autocephaly has existed for decades. Hence, we have examined the differences and similarities in the process in the two countries.
\end{abstract}

Keywords: church, autocephaly, state, nation, identity 